V.FAJER

L.ALVAREZ

\section{ORGANIC SCINTILLATOR EFFICIENCY} USING A MONTE CARLO CODE
Hungarian Fcademy of Sciences

\section{CENTRAL}

RESEARCH

INSTITUTE FOR

PHYSICS 


\title{
ORGANIC SCINTILLATOR EFFICIENCY USING A MONTE CARLO CODE
}

\author{
V. Fajer \\ Roland Eötvös University, Budapest \\ Budapest, VIII. Puskin u. 5-7. \\ L. Alvarez \\ Central Research Institute for Physics \\ Hungarian Academy of Sciences, \\ Budapest, XII. Konkoly Thege ut 29-33.
}

On leave from Nuclear Research Institute,
Academy of Sciences of Cuba, Managua, Havana,
P.O.B. 6122, Cuba 
The TAYRA code was developed for calculating the efficiency organic scintillators for neutrons in the energy range 0.08 to $15 \mathrm{MeV}$. The algorithm uses the Monte Carlo method and considers, for the simulation, elastic scattering on hydrogen and carbon, inelastic scattering on carbon, and the reactions: $12 \mathrm{C}\left(n, n^{\prime}\right)^{12} \mathrm{C}^{*}+3 \alpha$ and $12_{\mathrm{C}}(\mathrm{n}, \alpha){ }^{9} \mathrm{Be}$.

The code is written in FORTRAN IV for an ES 1040 computer. The results obtained using TAYRA are compared with experimental and calculated efficiency data.

\section{АНнОТАЦИЯ}

Программа ТАУРА разработана для определения эфФективности органических нейтронных детекторов в диапазоне 0.08-15 Мэв. В программе использовался метод Монте-Карло. В испытании учитываются упругие и неупругие рассеяния на $\mathrm{H}$ и $\mathrm{C}$ и тоже реакция $12 \mathrm{C}(\mathrm{n}, \mathrm{n},)^{2} \mathrm{C}^{*} \rightarrow 3 \mathrm{~d}$ и $12 \mathrm{C}(\mathrm{n}, \alpha) \mathrm{Be}^{9}$.

Программа написана на языке ФОРTPAH-IV, а использована на машине EC-1040. Реэультаты полученные программой ТАУРA были сопоставлены с экспериментальными и расчетными данными других авторов.

\section{KIVONAT}

A TAYRA nevü számitógépi program szerves szcintillátorok hatăsfokát számitja, $E=0.08-15 \mathrm{MeV}$ energiáju neutronok esetében. A program a Monte Carlo módszêrt használja fel a neutronok hidrogégen és szénen törrténố rygalmas, ill. rugalmatlan szórásának és a ${ }^{12_{C}}\left(n, n^{\prime}\right)^{12} C^{*}+3 \alpha$ és a ${ }^{12} C(n, \alpha)$ Be reakcióknak a szimulálására.

A program nyelve FORTRAN IV, ES 1040 tipusu számitógépre alkalmazva.

A program által számitott hatásfok értékeket kisérleti eredményekkel hasonlitottuk össze. 


\section{INTRODUCTION}

Organic scintillators have many applications in experimental cross section and nuclear reaction studies. Precise knowledge of the efficiencies of these scintillators is necessary in order to obtain the minimum possible errors in the final results.

The efficiency value is, at present, obtained in two ways: experimental and calculated.

The experimental way frequently uses the time-of-flight technique; the calculated way offers two possibilities, the employment of semi-empirical formulae and the Monte Carlo method. Inherent in the first possibility is the problem that the required correction factors are approximations and they are valid only in certain energy ranges. This means that larger errors arise than those desirable for accurate calculations of the efficiency.

The Monte Carlo method, which has been widely employed for this purpose, is the best way to calculate the efficiency value. It is based on the simulation of the physical events which take place inside the scintillator because of an incident neutron.

In order to improve the physical model, TAYRA code employs the cross sections obtained in small energy intervals. From 0.1 to $15 \mathrm{MeV}$ a constant energy interval of $0.1 \mathrm{MeV}$ was selected, and from 10 to $90 \mathrm{keV}$ a constant interval of $10 \mathrm{keV}$ was taken.

The lower energy range permits one to extend the efficiency calculation to a zone where the neutron detection has become feasible by fast plastic scintillators because of the development of low noise fast photomultipliers.

\section{NEUTRON HISTORY ANALYSIS}

TAYRA can calculate the efficiency for two geometrical arrangements for cylindrical scintillators: for a parallel beam of 
monoenergetic neutrons incident on the lateral surface of the scintillator, and for a beam of neutrons incident on the circular flat surface of the cylinder (Fig.1).

In order to begin the neutron history, it is necessary to determine the starting coordinates $(x, y, z)$. In the case of perpendicular incidence to the cylinder axts these are:

$$
\begin{aligned}
& x=A \sqrt{1-R^{2}}, \\
& y=A R 1, \\
& z=B R 2,
\end{aligned}
$$

where $A$ is the scintillator radius, $B$ is the half-height and $\mathrm{R} 1$ and $\mathrm{R} 2$ are two random numbers obtained from a uniform distribution between 0 and 1 .

The starting coordinates are points on the scintillator surface. In this case the direction cosines of the initial incidence direction are $\cos \alpha=-1, \cos \beta=0$, and $\cos \gamma=0$.

with parallel incidence to the cylinder axis, the $(x, y)$ coordinates are calculated in the same way and the $z$ coordinate is:

$$
\mathrm{z}=\mathrm{B}
$$

and the direction cosines are: $\cos \alpha=0, \cos \beta=0$ and $\cos \gamma=-1$.

In order to determine the next neutron coordinates, it is necessary to know the neutron free path in the scintillator, which is obtained by:

$$
\lambda(E)=\frac{1}{\Sigma_{T}(E)},
$$

where $\Sigma_{T}(E)$ is the total macroscopic cross section. With this value it is possible to determine the neutron path length, $\rho(E)$, by :

$$
\rho(E)=-\lambda(E) \text { ln } R 3,
$$

where $\mathrm{R} 3$ is another random number from the same distribution between $O$ and 1 . This value, $\rho(E)$, permits one to decide wheter the neutron escapes from the scintillator or, alternatively one can determine the new coordinates which correspond to the point where the first interaction takes place. 
Since the scintillator can be considered as a mixture of hydrogen and carbon atoms, the most probable interactions of fast neutrons with these nuclei to be taken into account in the energy range 0.02 to $15 \mathrm{MeV}$, are:
a. Elastic scattering on hydrogen nuclei,
b. Elastic scattering on carbon nuclei,
c. Inelastic scattering on carbon nuclei,
d. The reaction ${ }^{12} \mathrm{C} n, \mathrm{n}^{\prime} \mathrm{C}^{*} \rightarrow 3 \alpha$,
e. The reaction ${ }^{12} \mathrm{C}(\mathrm{n}, \alpha) \mathrm{Be}^{9}$.

The cross section values were obtained from reference [1].

\subsection{Elastic scattering on hydrogen nuclei}

Elastic scattering on hydrogen nuclei is the most probable interaction below $10 \mathrm{MeV}$. From this collision are obtained a scattered neutron and a recoil proton, and their energies after the scattering are:

$$
\begin{aligned}
& E_{P}=\frac{1}{2} E_{O}(1-\cos K) \\
& E_{n}=\frac{1}{2} E_{0}(1+\cos K)
\end{aligned}
$$

where $E_{0}$ is the incident neutron energy and $k$ is the scattering angle in the centre of mass system, where the elastic scattering is isotropic [2].

The magnitude of the light output produced by the recoil proton is one of the most problematic aspects of the physical model. In order to improve this aspect, light output values recently obtained or confirmed, have been employed. Tabulated values obtained from [3] have been used in the energy range 20 to $200 \mathrm{keV}$, and the following semi-empirical formula given in [4] is employed in the range 0.2 to $15 \mathrm{MeV}$ :

$$
L_{P}=a_{1}\left[1-\exp \left(-a_{2} E_{P}^{a_{3}}\right)\right]+a_{4} E_{P^{\prime}}
$$

where $a_{1}, a_{2}, a_{3}$ and $a_{4}$ are parameters which depend on the 
scintillator type. This physical event is considered in the TAYRA code in the subroutine HYDR.

\subsection{Elastic scattering on carbon nuclei}

The result of this collision is a recoil carbon nucleus and a scattered neutron with energies:

$$
\begin{aligned}
& E_{C}=0.142 E_{O}(1-\cos K), \\
& E_{n}=E_{O}-E_{C}
\end{aligned}
$$

In the scintillator the carbon nucleus produces a light output whose magnitude is calculated, as is shown in [5], by:

$$
L_{c}=0.01 E_{C}
$$

The anisotropy of this event in the centre of mass system is taken into account. The angular distribution values were taken from [1]. The probabilities of the different directions are calculated from these angular distributions. This event is simulated in the TAYRA code in the subroutine ELAC.

\subsection{Inelastic scattering on carbon nuclei}

This interaction produces a gamma ray of $4.43 \mathrm{MeV}$ and an outgoing neutron, and it becomes important for incident neutrons of low energies. The light output produced by the gamma ray is not taken into account because the detection efficiency is poor for its energy, for details see ref. [5].

The main effect of this interaction is to decrease the neu tron energy in $4.43 \mathrm{MeV}$ without changing its direction. 
2.4 The reaction ${ }^{12} \mathrm{C}\left(\mathrm{n}, \mathrm{n}^{\prime}\right) \mathrm{C}^{*}+3 \mathrm{~d}$

This reaction begins to be important above $11 \mathrm{MeV}$ and remains with low probability at $14 \mathrm{MeV}$. Nevertheless, it gives three alpha particles with energies, In the laboratory system, in the range 1 to $3 \mathrm{MeV}$; each alpha particle produces a light output of approximately $100 \mathrm{keV}$ in electron equivalent energy.

In the TAYRA code, when this event takes place, the produced neutron is detected if the selected threshold is lower than $3 \mathrm{MeV}$.

\subsection{The reaction ${ }^{12} \mathrm{C}(\mathrm{n}, \alpha) \mathrm{Be}^{9}$}

In this reaction an alpha particle and a beryllium nucleus are produced, whose energies are:

$$
\begin{aligned}
& E_{\alpha}=\left(E_{n}-Q\right)(B+D+2 \sqrt{A C} \cos K) \\
& E_{B e}=\left(E_{n}-Q\right)(A+C-2 \sqrt{A C} \cos K),
\end{aligned}
$$

where $A, B, C$ and $D$ are coefficients which depend on the mass of the nuclei and particles that take part in the reaction, and they also depend on the neutron energy, E, and the Q-value of the reaction, $(-5.71 \mathrm{MeV})$. These coefficients are given in ref.[6].

The light output produced by the ${ }^{9} \mathrm{Be}$ nucleus can also be obtained using the formula (9). The light output of the alpha particle can be determined by the following formula used in ref.[2]:

$$
\mathrm{L}_{\alpha}=0.046 \mathrm{E}_{\alpha}+0.007 \mathrm{E}_{\alpha}^{2}
$$

The anisotropy in the centre of mass system is also considered in this event; a constant angular distribution, measured and fitted in ref. [7], was used for the whole energy range. These calculations are taken into account in the TAYRA code in the subroutine I.LPHAN. 
The event which takes place is determined thereby generating a random number. This number is then compared with the occurrence probability of each event. The probabilities are previously assigned taking into account the cross sections.

The new direction of the scattered neutron, after each interaction, is calculated to enable the new coordinates to be located.

When the interaction is considered isotropic in the centre of mass system, the cosine of polar scattering angle of the outgoing particle, cosk, and the azimuthal angle $\phi$ can be randomly generated, cosk is generated from a uniform distribution between -1 and +1 by:

$$
\cos K=2 \text { R5 }-1,
$$

where R5 is a random number between $O$ and 1. The cosine of $\phi$ only takes values between 0 and 1 .

If the interaction is considered anisotropic, cosk is taken from the correspondent angular distribution.

The scattering angle in the laboratory system, $\theta$, is calculated by the following formulae:

$$
\begin{aligned}
& \cos \theta=\left(1+m_{2} \cos \kappa\right) / \sqrt{1+2 m_{2} \cos k+m_{2}^{2}}, \\
& \sin \theta=m_{2} \operatorname{sink} / \sqrt{1+m_{2} \cos \kappa+m_{2}^{2}},
\end{aligned}
$$

where $m_{2}$ is the mass of the scatterer nucleus.

The direction cosines after the scattering are, as is shown in ref. [8]:

$\cos \alpha^{\prime}=\cos \alpha \cos \theta+(\cos \gamma \cos \alpha \sin \theta \cos \phi-\cos \beta) \sin \theta \sin \phi /\left(1-\cos ^{2} \gamma\right)^{1 / 2}$, $\cos \beta^{\prime}=\cos \beta \cos \theta+(\cos \gamma \cos \beta \sin \theta \cos \phi+\cos \alpha \sin \theta \sin \phi) /\left(1-\cos ^{2} \gamma\right)^{1 / 2}$, $\cos \gamma^{\prime}=\cos \gamma \cos \theta-\left(1-\cos ^{2} \gamma\right)^{1 / 2} \sin \theta \cos \phi$,

except when $\left(1-\cos ^{2} \gamma\right)$ approaches zero, in which case the following equations are used:

$$
\begin{aligned}
& \cos \alpha^{\prime}=\sin \theta \cos \phi \\
& \cos \beta^{\prime}=\sin \theta \sin \phi \\
& \cos \gamma^{\prime}=\cos \gamma \cos \phi
\end{aligned}
$$


These equations are employed in the subroutine COSINE.

The history is interrupted when the neutron escapes from the scintillator or its energy is diminished below the selected cut-off ( $20 \mathrm{keV})$, then the neutron is absorbed by the scintillator. When a light pulse or a sequence of pulses, whose total magnitude is greater than the light threshold, is produced, the history of the neutron is also interrupted.

Finally the efficiency value is obtained from the ratio of the detected neutrons to the number of histories followed, and the relative and absolute errors are also calculated by the TAYRA code.

\section{RESULTS AND CONCLUSIONS}

The Monte Carlo program was employed to calculate efficiency values of different organic scintillators. The results were compared with some available experimental data from refs.[9] and [10]; the agreement between experimental and Monte Carlo values was found to be reasonable as is shown in Tab. 1. and Fig. 2 .

The experimental data taken from ref.[9] were also compared with the Monte Carlo predictions of [5] and it was found that the TAYRA code gives also good agreement with these measurements.

In general, one can observe that the disagreement between the measured and the calculated efficiencies is around $10 \%$ overal1, and this seems to be produced because of the uncertainties in the inelastic $n-C$ cross sections [11], and in the light output values of the a particles and the ${ }^{12} \mathrm{C}$ and ${ }^{9} \mathrm{Be}$ nuclei. Furthermore, the Monte Carlo calculations have not taken into account the light attenuation effects inside the scintillator and in the optical coupling.

It was obviously important to be extremely careful in the simulation of each experimental condition of the measurements, especially in the selection of the light threshold.

The results of TAYRA were also compared with some efficiency values obtained by other Monte Carlo calculations, from refs. [3], [6] and [12]. The comparison with the predictions of [3] 
was possible because of the use of a small energy interval, $20 \mathrm{keV}$. in the range 20 to $200 \mathrm{keV}$, and also because the cut-off energy was lowered, (Fig. $3 a$ ).

In this way the TAYRA code can calculate the efficiency values in the energy range from 80 to $500 \mathrm{keV}$, which is very important nowadays because the development of low nolse photomultiplier tubes and organic scintillators with large light output has permitted the use of these neutron detectors in this range.

The results given in [3] were obtained using a modified version of the O5S code developed by Textor and Verbinski, ref.[6]. The results from TAYRA were also compared with the predictions of the O5S code, as is shown in $T a b .2$ and Fig. $3 b$.

The very small discrepancies between the TAYRA results and the other predictions seem to be because of the employment of different cross section values for the $n-C$ interactions and also because of the introduction in the TAYRA code of a semiempirical formula for the light output of the recoil proton, formula (6) given in ref.[4]. This formula gives good agreement with the experimental data of other authors.

Finally, Fig.4. shows the efficiency curve for an NE-102 A scintillator obtained using an interval of $0.5 \mathrm{MeV}$ in the energy range 1 to $15 \mathrm{MeV}$. These results were fitted by:

$$
E_{F}=\left(1-T / E_{n}\right)\left(A_{0}+A_{1} E_{n}+A_{2} E_{n}^{2}+A_{3} E_{n}^{3}+A_{4} E_{n}^{4}\right)
$$

where $E_{F}$ is the efficiency, $T$ is the threshold in proton energy and the values of the parameters were: $A_{0}=73.38$, $A_{1}=-20.75, A_{2}=3.32, A_{3}=-0.24$ and $A_{4}=0.64$.

The execution time for a run was approximately $30 \mathrm{sec}$ for 10000 histories and the relative error was less than $3 \%$ in all the runs.

\section{ACKNOWLEDGEMENTS}

We are grateful to A. Kiss and F. Deâk for their comments and helpful discussions related to this work. The help of 
Lic. J.M. Hernandez and B. Barrios in the preparation of the code is appreciated. We wish to thank Dr. I.Fodor and Dr.J.Sziklai for their kind hospitality in the Central Research Institute for Physics, Budapest, where it was possible to develop the TAYRA code. 


\section{APPENDIX}

Summary of program components and input data

System: ES-1040

Language: FORTRAN IV

Components:

1. Main program: TAYRA

2. Subroutines:

a. CARG. Provides the cross sections for the considered events and also the necessary angular distributions and the tabulated data of light output in the energetic range from 20 to $200 \mathrm{keV}$. This subroutine also stores the scintillator data.

b. PROBA(E). Chooses the probabilities for the neutron energy and these are stored in the blank COMMON.

c. COSENO(SITA, ALF, BET, GAM). Computes the centre of mass cosines of the polar scattering direction in both cases: 1sotropic and anisotropic scattering, and uses them to calculate the new direction cosines in the laboratory system.

d. HYDR(ENE,SITA,P). Computes the energies of the scattered neutron and the recoll proton when elastic scattering on hydrogen takes place, and also computes the light output due to the recoil proton.

e. ELAC (ENE, SITA,P). Computes the same as HYDR in the case of elastic scattering on carbon.

f. ALPHAN(P). Calculates the energies and the light output of the alpha particle and the beryllium nucleus when the reaction ${ }^{12} \mathrm{C}(n, \alpha) \mathrm{Be}^{9}$ takes place.

3. FORTRAN functions:

a. RANDOM(KS). Computes random numbers uniformly distributed between $O$ and 1 , using any odd number as input parameter. 
b. $\operatorname{SEGN}(\mathrm{X})$. Attributes values +1 or -1 if the argument $X$ is negative or positive.

c. ALAMDA(ENE). Computes the mean free path of the neutron depending on its energy ENE.

4. INPUT DATA:

a. CARD SET 1, one card, OL(10)

FORMAT (1OF7.0)

OL(I): light output in the energetic range from 20 to $200 \mathrm{Kev}$ with $20 \mathrm{Kev}$ as step.

b. $\operatorname{CARD} \operatorname{SET} 2$, two cards, $\operatorname{SEM}(8,2)$

FORMAT ( 8F10.0)

$\operatorname{SEM}(J, I)$ : cross sections in the energetic range from 20 to $90 \mathrm{Kev}$ with $10 \mathrm{Kev}$ as step, J is the index for the energy and $I$ is for the interaction channels in this energetic range (elastic scattering on hydrogen and carbon).

C. CARD SET 3, 75 cards, $\operatorname{SE}(150,5)$

FORMAT ( IOF 8.0)

$\mathrm{SE}(\mathrm{J}, \mathrm{I})$ : cross sections in the energetic range from 100 Kev to $15 \mathrm{Mev}$ with $0.1 \mathrm{Mev}$ as interval, J is the index for the energy and $I$ is for the interaction channels.

d. CARD SET 4, 3 cards, PE(42)

FORMAT (16F5。0)

$\mathrm{PE}(I)$ : energetic groups for the angular distributions of the elastic scattering on carbon.

e. CARD SET 5, 126 cards, $A D(21,42)$ FORMAT (7F10.0)

$\mathrm{AD}(\mathrm{J}, \mathrm{I})$ : angular distributions of the elastic scattering on carbon, $J$ is the index for the energy and I for the value of the cosine of the scattering angle in the centre of mass system.

f. CARD SET 6, 3 cards, $A D A(21)$ FORMAT (7F10.0)

$A D A(I):$ angular distributions for $14 \mathrm{Mev}$ of the reaction ${ }^{12} \mathrm{C}(n, \alpha) \mathrm{Be}^{9}$ which is taken to remain the same in the whole energy range. 
g. CARD SET 7, one card, HN, RHC, A, C, G

FORMAT (5F10.0)

HN : number of hydrogen atoms/cm-barn,

RHC: hydrogen/carbon ratio,

A: scintillator radius,

B: scintillator half height,

G: geometry code, $\mathrm{G}=1$ if the neutron incldence is perpendicular to the cylinder axis and $G=2$ if the neutron incidence is parallel to this one.

CARD SET 8 , one card, RN

FORMAT (FIO.0)

RN: number of neutron histories.

1. CARD SET 9, one card, EMI, UMBRAE

FORMAT (2F10.0)

EMI: cut off energy,

UMBRAE: energetic threshold.

j. CARD SET 10, as many cards as you need, EI FORMAT (F10.0)

EI: initial neutron energy, if it is necessary to cons1der more than one energetic threshold one must put a last card of the set 10 with $E I=0$, and after a card of the set 9 and so on. If one needs to finish the sequence it is necessary to put a last card of the set 10 with $\mathrm{EI}=-1$.

NOTE: When using the TAYRA code to calculate different efficiencies for different experimental arrangements, the only change is to alter card sets $7,8,9$ and 10 . 


\section{REFERENCES}

1) P. Vértes, FEDGROUP - A program system for producing group constants from evaluated data files disseminated by IAEA: INDC (HUN) $-13 / \mathrm{L}+\mathrm{sp}, 1976$.

2) R. Batchelor and W.B. Gilboy, Nucl. Instr. and Meth. $13(1961) 70$.

3) C. Renner, N.W.H111, G.L.Morgan, K. Rush and J.A. Harvey, Nucl. Instr. and Meth. 154 (1978) 525.

4) R. Madey, F.M. Waterman, A.R. Baldwin, J.N. Knudson, J.D. Carlson and J. Rapaport, Nucl. Instr. and Meth.151(1978) 445.

5) R.J. Schuttler, ORNL-3888, (1966).

6) R.E. Textor and V.V. Verbinski, ORNL-4160, (1968).

7) M.L. Chaterjee and B. Sen, Nucl. Phys. 51 (1964) 583.

8) G.B. Beam, L. Wielopolski, R.P. Gardner and K. Verghese, Nucl. Instr. and Meth. 154 (1978) 501.

9) T.A. Love, R.T. Santoro, R.W. Peelle and N.W. Hill, Rev. Sci. Instr. 39 (1968) 541, No.4.

10) P. Leleux, P.C. Macq. J.P. Meulders and C. Pirart, Nucl. Instr. and Meth. 116 (1974) 41.

11) A. Del Guerra, Nucl. Instr. and Meth. 135 (1976) 337.

1.2) V.V. Verbinski, W.R. Burrus, T.A. Love, W. Zobel, N.W. Hill and R. Textor, Nucl. Instr. and Meth. 65 (1968) 8. 
Table 1.

Comparison of calculated and experimental efficiency values for a bias threshold - $180 \mathrm{keV} \mathrm{p.e.q.} \mathrm{for} \mathrm{two} \mathrm{NE-213} \mathrm{scintillators} \mathrm{and}$ neutron incidence parallel to the cylinder axis.

\begin{tabular}{ccccc}
\hline $\begin{array}{c}\text { Scintiliator } \\
\text { dimensions } \\
\mathrm{cm}\end{array}$ & $\begin{array}{c}\text { Neutron } \\
\text { energy } \\
\mathrm{MeV}\end{array}$ & $\begin{array}{c}\text { TAYRA } \\
\text { code } \\
8\end{array}$ & $\begin{array}{c}\text { Experimental } \\
\text { Ref.[9] } \\
8\end{array}$ & $\begin{array}{c}\text { Calculated } \\
\text { Ref.[5] } \\
8\end{array}$ \\
\hline $12 \times 2.61$ & 2.7 & $16.97+0.20$ & $17.22+0.11$ & -- \\
$12 \times 6.10$ & 14.5 & $10.06+0.16$ & $10.62+0.08$ & 9.70 \\
& 2.7 & $30.40+0.28$ & $33.75+0.15$ & --- \\
& 14.5 & $20.89+0.23$ & $22.60+0.20$ & 21.70 \\
\hline
\end{tabular}

Table 2 .

Comparison of calculated efficiencies by two different codes for an NE-213 scintillator, bias threshold $=0 \mathrm{keV}$ and neutron inc1dence perpendicular to the cylinder axis.

\begin{tabular}{cccc}
\hline $\begin{array}{c}\text { Scintillator } \\
\text { dimensions } \\
\mathrm{cm}\end{array}$ & $\begin{array}{c}\text { Neutron } \\
\text { energy } \\
\mathrm{MeV}\end{array}$ & $\begin{array}{c}\text { TAYRA } \\
\text { code } \\
8.419 \times 9.174\end{array}$ & $\begin{array}{c}\text { O5S } \\
\text { code, Ref. [6] } \\
8\end{array}$ \\
\hline
\end{tabular}




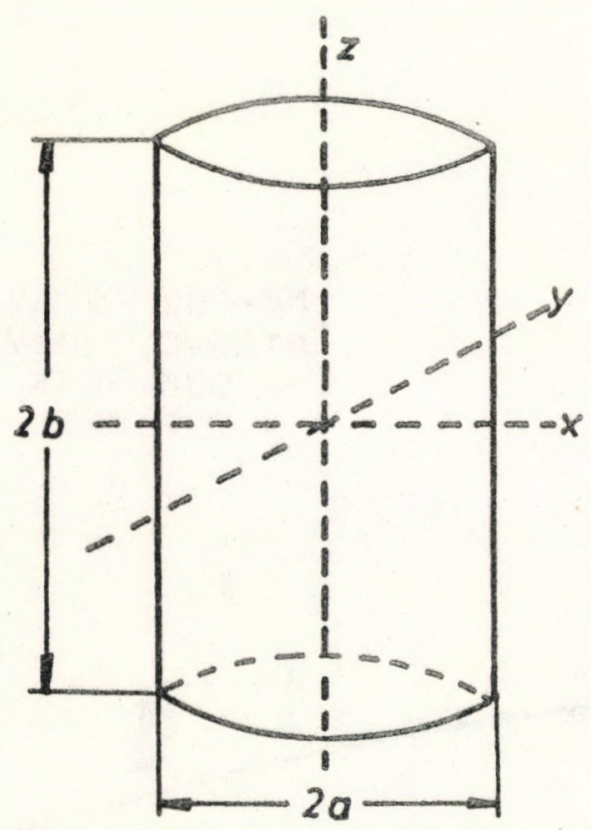

neutron beam

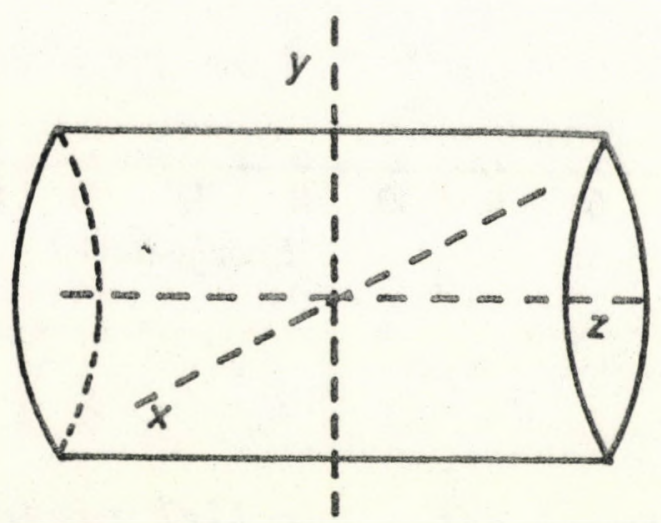

neutron beam

Eig.1. Geometrical arrangements that can be simulated by the TAYRA code. 


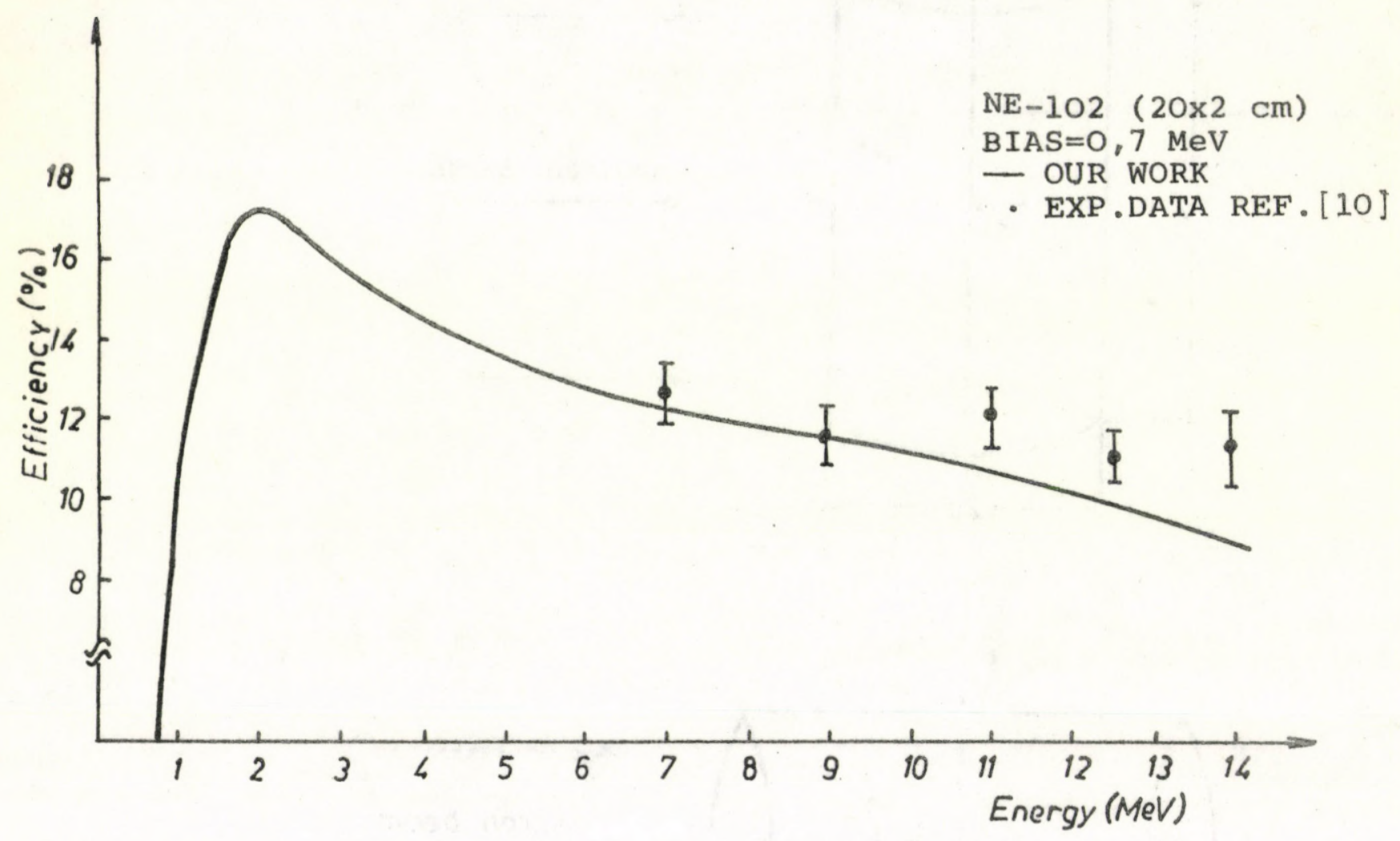

Fig.2. Comparison with experimental data. Parallel neutron incidence to the cylinder axis. Diameter: $20 \mathrm{~cm}$. Height: $2 \mathrm{~cm}$. 

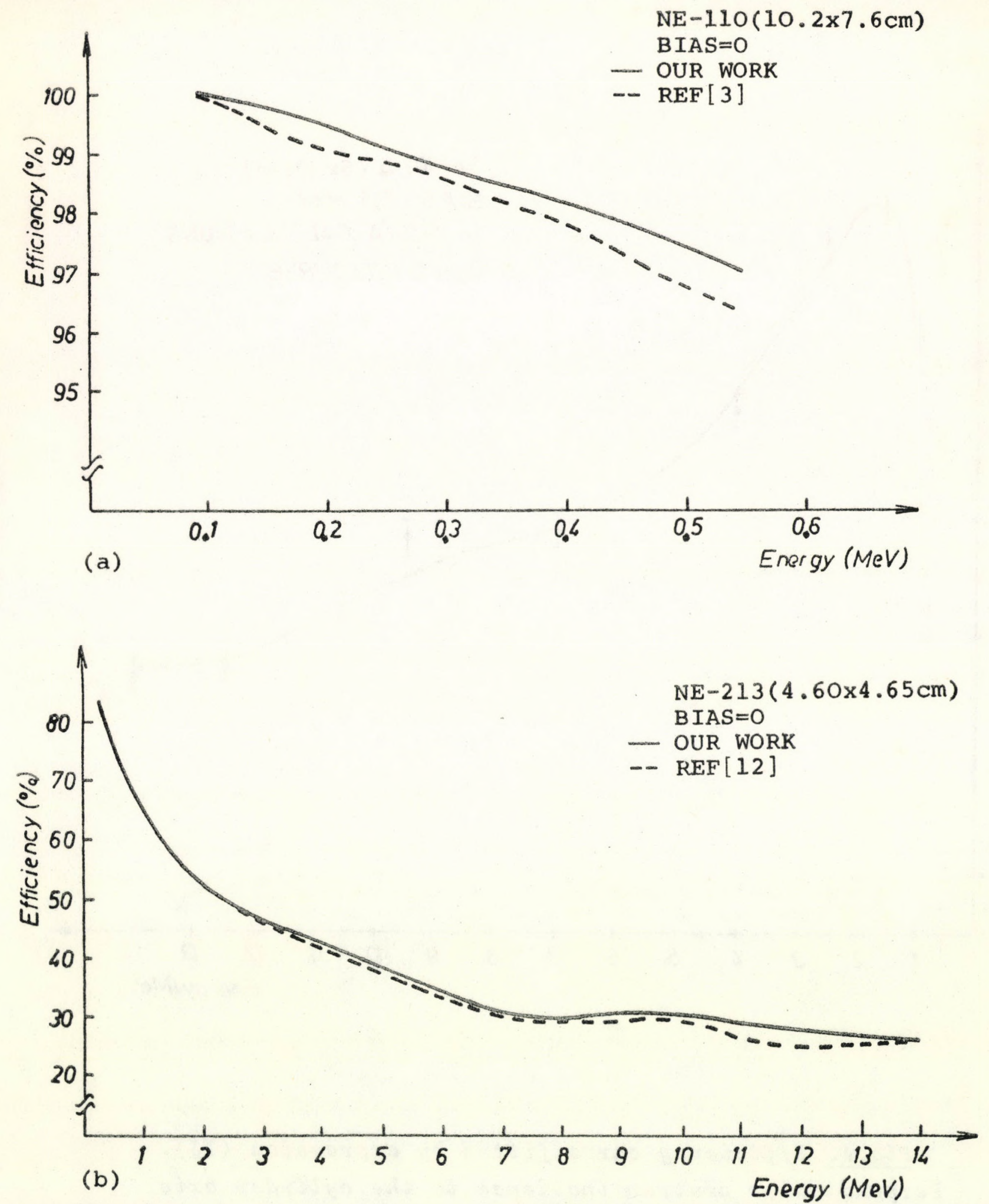

Fig.3. Comparison of TAYRA calculations with other predictions: (a) 05 modified; (b) 055 code. Parallel neutron incidence to the cylinder axis. 


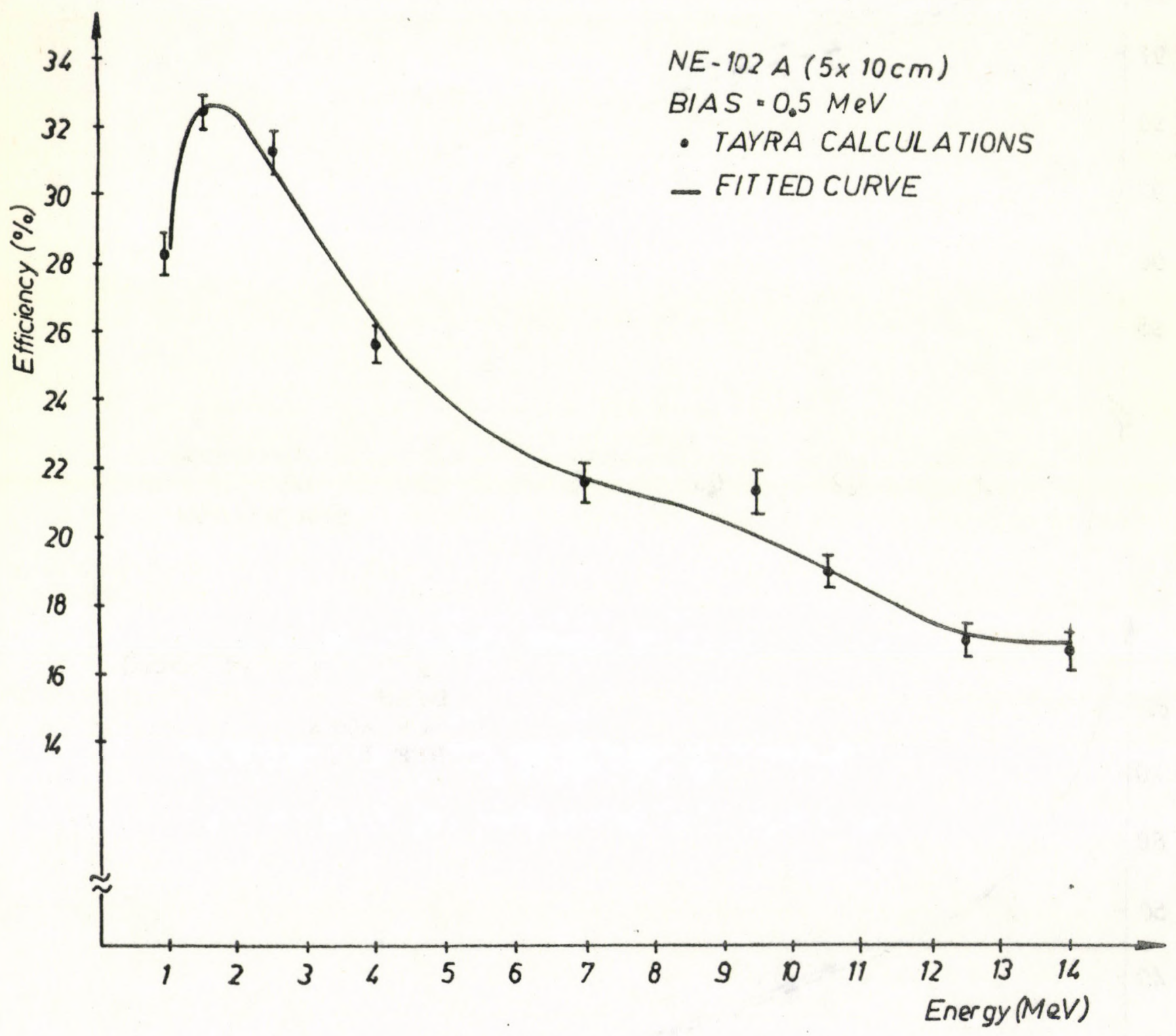

Fig.4. Efficiency curve fitted by expression (13). Perpendicular neutron incidence to the cylinder axis. Diameter: $5 \mathrm{~cm}$. Height: $10 \mathrm{~cm}$. 
$-19-$

TAYRA LIST ING 
MAI"

OATE $=79950$

$11 / 16 / 27$

CODOMONTE CARLO CODE BOR CALCULATING EFFICIENCIES OF ORGANIG SCINT.

COMPON/LIGH /OL

COM"ON,AK\&, ENE, PE(42), AD (29,42), ADN(29)

COHION/JH/HN, RHC, A, B, G

COMPON/SEMI/KS

COMPOON/HILOA,RHA, RII

$6 \infty-\infty$ IN PHE BLANK COHMON"ARE ACUPULATED THE PROBABILBTIES GOR

6 THE EVENTS CONSIDERED

COINON PNP, PEC, DNG, PSA, PA

RMIः1 .

CALL CARG

READ $(5,900, R N$

400 READ $(5,900)$ EM $\$, U M B R A E$

WRITE $(6.909) \mathrm{G}$

WRITE $(6,800) A, B$

WRITE $(6.802) R N$

WRITE $(6,803)$ EM\&, UMBRAE

605 READ $(5,900) \mathrm{kg}$

$K S \equiv 157$

WR ITE $(6, B O S) E$ I

IF (EI) $490,400,620$

W 10 STOP

$420 R Y=0$

RNDE $=0$

$R H \equiv O$

$R C=O$

$R G=0$

$R E=0$

$X L=0$

COWO-IF PIIE ENERGETIC THEESHOLO IS LARGER THAM O.2 MEV, THE LIGIIT

C THRESHOLD IS CALCULATED BY A SEHI-EMPYRICAL FORMULA, IF IT IS

C LOWER PHAN 0.2 MEV TABULATED DATA ARE TAKEN,

IF (II)BRAE) $500,500,501$

SOO IJMBRAL $=0.00001$

$G O$ TO 140

509 IF (UHBRAE 0.2$) 502,5,2,503$

OZ UMBRALOLLPIFIX( ( (UMBRAE\$.01)/2, )*100.)

GO TO 140

SOS T,UE. 95 UMBRAE

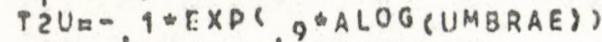

T $3 U=-8.19 .-\dot{E} X P(T 2 U))$

UMBRALETIU⿻ I $3 U$

१४० ENE $=E$ ?

C $O$ PHE POSITION OF THE INCIDENT NEUTRON IS CALCULATED USING THE

C RAPDOM NUMBERS RI A:O R2. IF THE KEY GE THE INCIDENCE IS PERP, TO

C THE CYLINDER AKISI IF GEZ IS $1 /$, AND THE PROCFDURE IS DIFERENT.

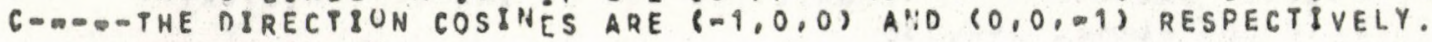

$R q=R A N O O M$ RS,

$X=A \backsim S Q R T(1 .-R Q \oplus 2)$

$Y=A \notin R I$

IF $(G-2) 1901,9902,$,

1४० $A L F=-1$

BET $=0$

$G A^{M}=0$

R2:RANOOHQKS)

$2 \approx B \sqcap R 2$

$H=2, * X$ 
MA::

DATE $=79150$

$11 / 16 / 27$

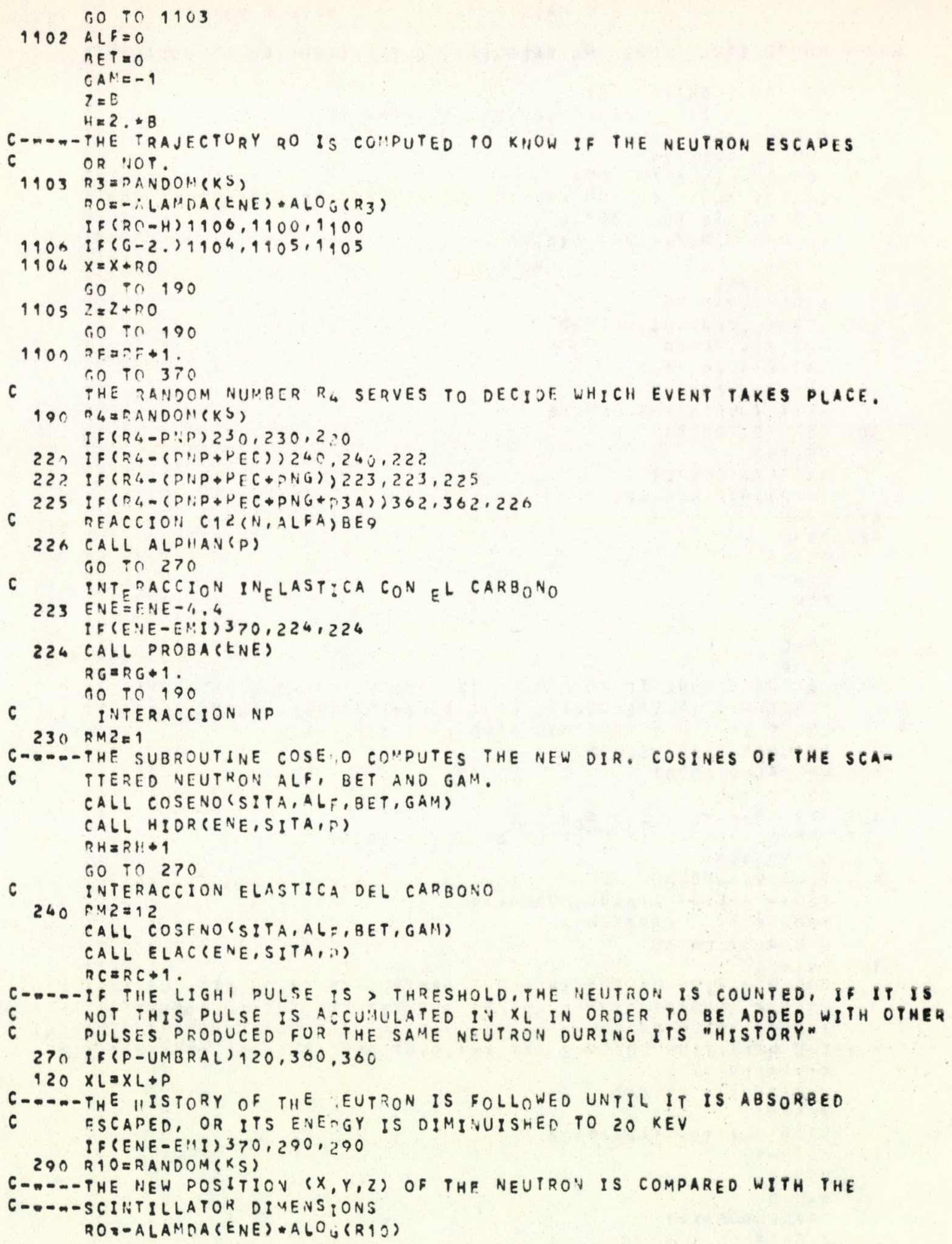




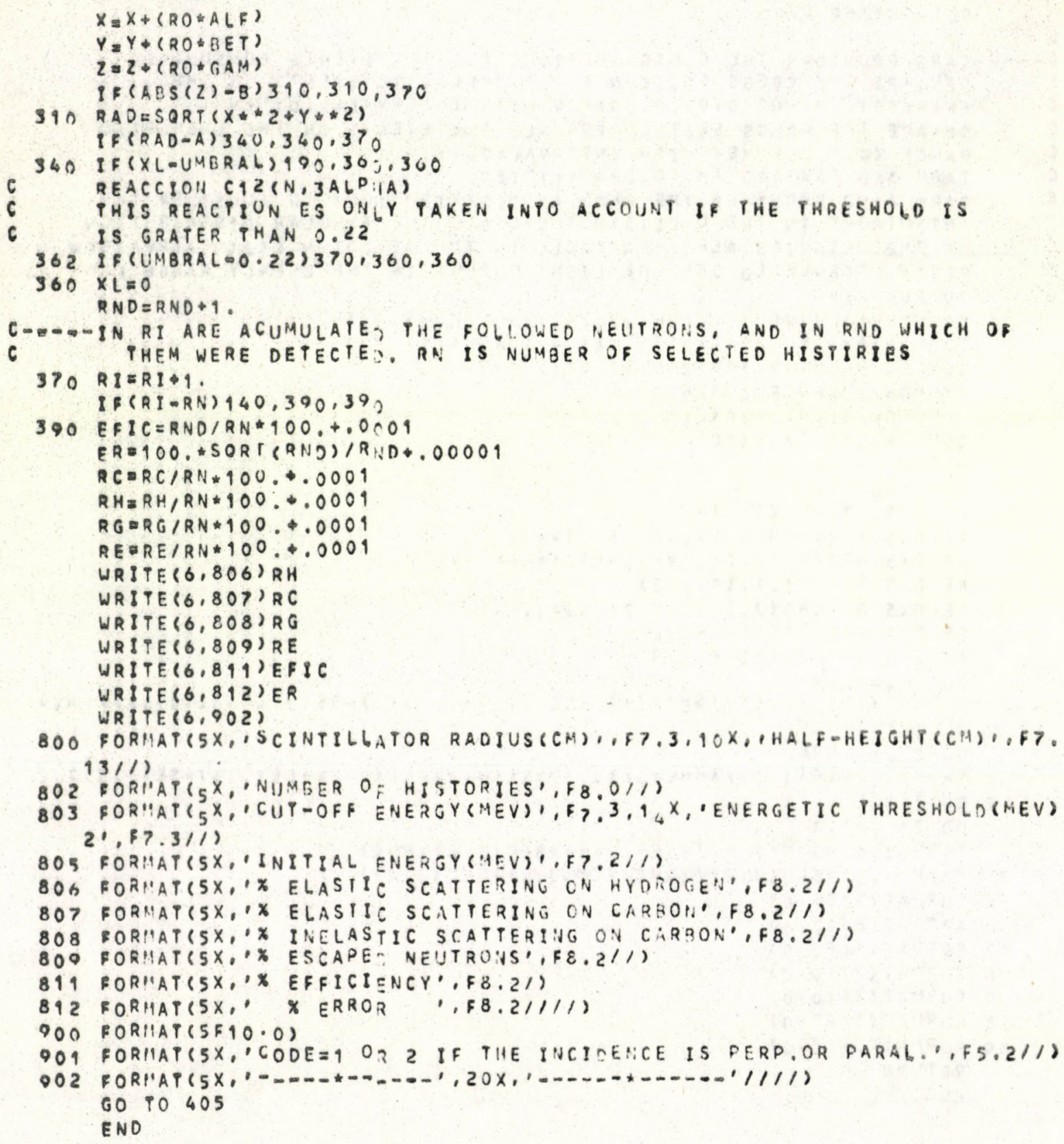




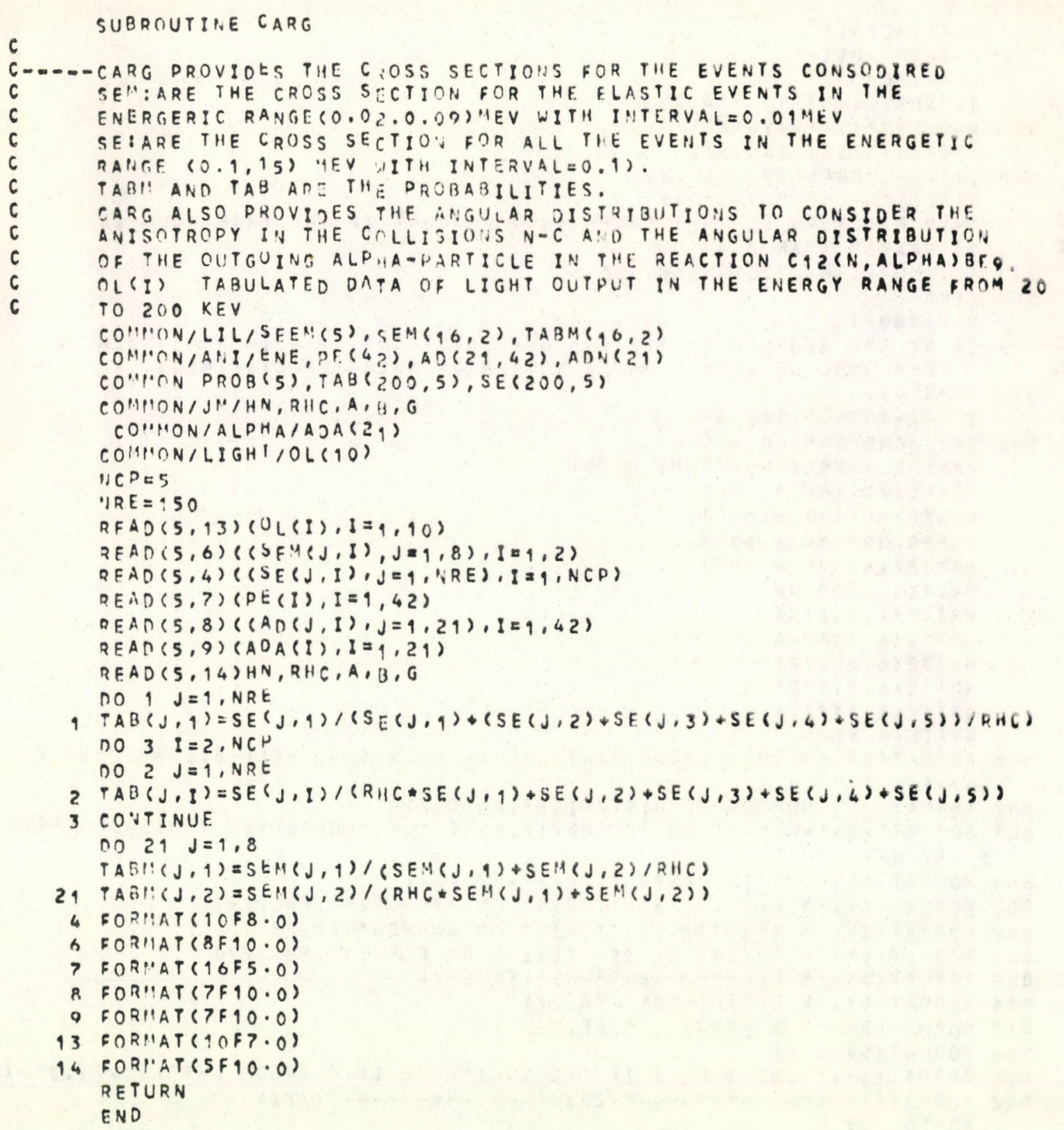


SUBROUTINE PROBACE?

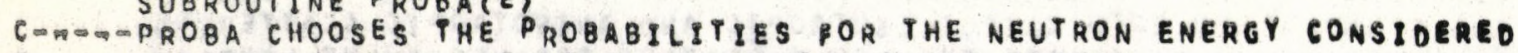

6 AND THESE ONES ARE STORAGEO EN PHE BLANK GOMMON.

COMPOON/LIL/SEEM(S), SEM( 16,2), TABM(16,2)

COMNON PROB $(5), T A B(200,3)$

COHIION/JM/HN, RHC, A, B, G

IF $(E-0.1) 1,2,2$

$2 D O 20 \quad I=1,5$

20 DROB $(1)=T A B(I F I X(E * 10 .+.5001) .8)$

GO TO 3

I OO $29 \quad I=1,2$

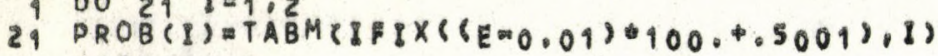

$P R O B(3)=0$

$P R O B(4)=0$

$P R O B(5)=0$

S CONTINUE

RE PURN

END 
SUBROUTINE COSENOSSITA, ALF, BET,GAM,

c COMHON/ANI/ENE, PE (42), AD $(29,42), A D N(21)$

C-m-n-COSENO COMPUTES THE CENTER OF MASS COSINE OF POLAR SCATIERING ANGLE (SITA) IN BOTH CASESI ISOTROPIC AND ANISOTROPIC SCATYERIHG, AND USES IT TO CALCULATE THE NEW DIRECTION COSINES INTHE LABORATORY SYSTEM.

COHP:ON/HILOA/RM,,$R M_{2}$ COMMON/SEM!/KS

IF $(R M 2-12) 10,11,$,

$10 R_{5}=R A N D O M(K S)$

$S I T A=\left(2, * R_{5}\right)-1.00001$

GO TO 14

१1 RqZ 2 RANDOM(KS)

IF (ENE.GE, 10.89$) 00$ TO 16

$D O Q J=1,49$

$D=((P E(J)+P E(J+1))) / 2, \triangle P E(J)$

IF $(P E(J), L E \cdot(E N E+D), G O$ TO 95

IF ( $(E N E+D)$. LT.PE( 1$) ; G 0$ YO 10

15 IF $((E N E+D), L T, P E(J+q)) G O$ TO 92

1 CONTINUE

$12 L=J$

00 TO 17

$16 L=42$

17 DO $13 \quad I=1,21$

$13 A D N(I)=(A D(1, b)) / 9.67918$

$S A=0$

$D O \quad 40 \quad K=1,21$

$S A=A D N(K)+S A$

IF $(R 12-S A) 21,29,40$

40 CONTINUE

$29 \quad 14=K$

22 SITA $=F L O A T(M-11) / 10$.

$14 R 8=R A N D O M(K S$ )

$X=R 8-0.5$

$S S ! T A=S E G N(X) \neq S Q R T(1 .-S ! T A \star 2)$

$6 R G=R A N D O M(K S)$

$X=R 6$

$R T=R A N D O N(K S)$

$Y=(2 . * R>)-1$.

$B=X * 2+Y * * 2$

IF $(Q-9) 5,5,$,

$5 \mathrm{CPHI}=((Y * * 2)-(X * * 2)) / 0$

$S P H I=(2, * X * Y) / Q$

$R Q=R A N D O M(K S)$

$X=R 9-0.5$

$A=S E G N(X) * S Q R T\left(1+* 2, * R M_{2} * S I T A+\left(R M_{2} * \|_{2}\right)\right)$

CCHI $=(9 .+R(12 * S I T A) / A$

$S C H I=\left(R M Z * S S_{I} T A\right) / A$

$B=1,-G A M * \star 2$

I $F(B)>, 8,7$

$7 R 11=R A N D O M(K S)$

$X=R \uparrow 1-0.5$

$B B=S E G N(X) \star S Q R T(B)$

$A L F=A L F * C C H I+(G A M * A(F * S C H I * C P H I-B E T * S C H I * S P H I) / B B$

$B E T=B E T \star C C H I+(G A M * B E T * S C H I * C P H I+A L F * S C H I * S P H I) / B B$

$G A M=G A M * C C H I-B B * S C H I * C P H I$

$G O$ TO 9 
$8 \quad A L F=S C H I * C P H I$ $B E T=S C H I_{*} S P H Y$ $G A M=G A M * C P H I$

- RETURN

END 
$H I D R$

SUBROUTINE HIDR,ENE, SITA,P,

C-O--HIDR COMPUTES THE EIIRGIES OF THE SCATYERD NEUTRON AND THE RECOIL

6 PROTON WHEN THE ELASTIC SCATPERING WITH HYOROGEN TAKES PLACE,

C AND ALSO COMPUTES THE LIGHT OUTPUT DUE TO THE RECOSL PROTON.

COMHON/LIGHT/OL $(10)$

$E D R=E N E *(1,0-S I T A) / 2.0$

$E N E=F N E *(1.0+S I T A) / 2.0$

IF $(E P R-0,02) 5,6,6$

$5 P=0.00001$

00 TO 4

6 I $F(E P R-0,2) 2,2,3$

$2 P=O L(I F I X((C E P R+.01) / 2) * 100)$.

$G O$ TO 4

$3 T_{1}: .95 * E P R$

$T 2=-1 \neq E X P(. Q * A L O Q(E P R))$

$T 3=-8 . *(1,-E X P(T 2))$

$P=T_{1}+T_{3}$

4 CONTINUE

RETURN

END 
ELAC

DATE $=79950$

$11 / 96 / 27$

CD- - ELAC COMPUTES THE SAME AS HIOR IN THE CASE OF ELASTIC SCATTERING

C WITH CARBON.

SUBROUTINE ELAC (ENE, SITA, P)

$E C=0.142$ ENE * $(1,-S I T A)$

$E N E=E N E-E C$

$P_{2} 0.09 * E C \$ 0.00009$

RETURN

END 


\section{ALPHAN}

DATE $=79150$

$11 / 16 / 27$

SUBROUTINE ALPHAN\&P,

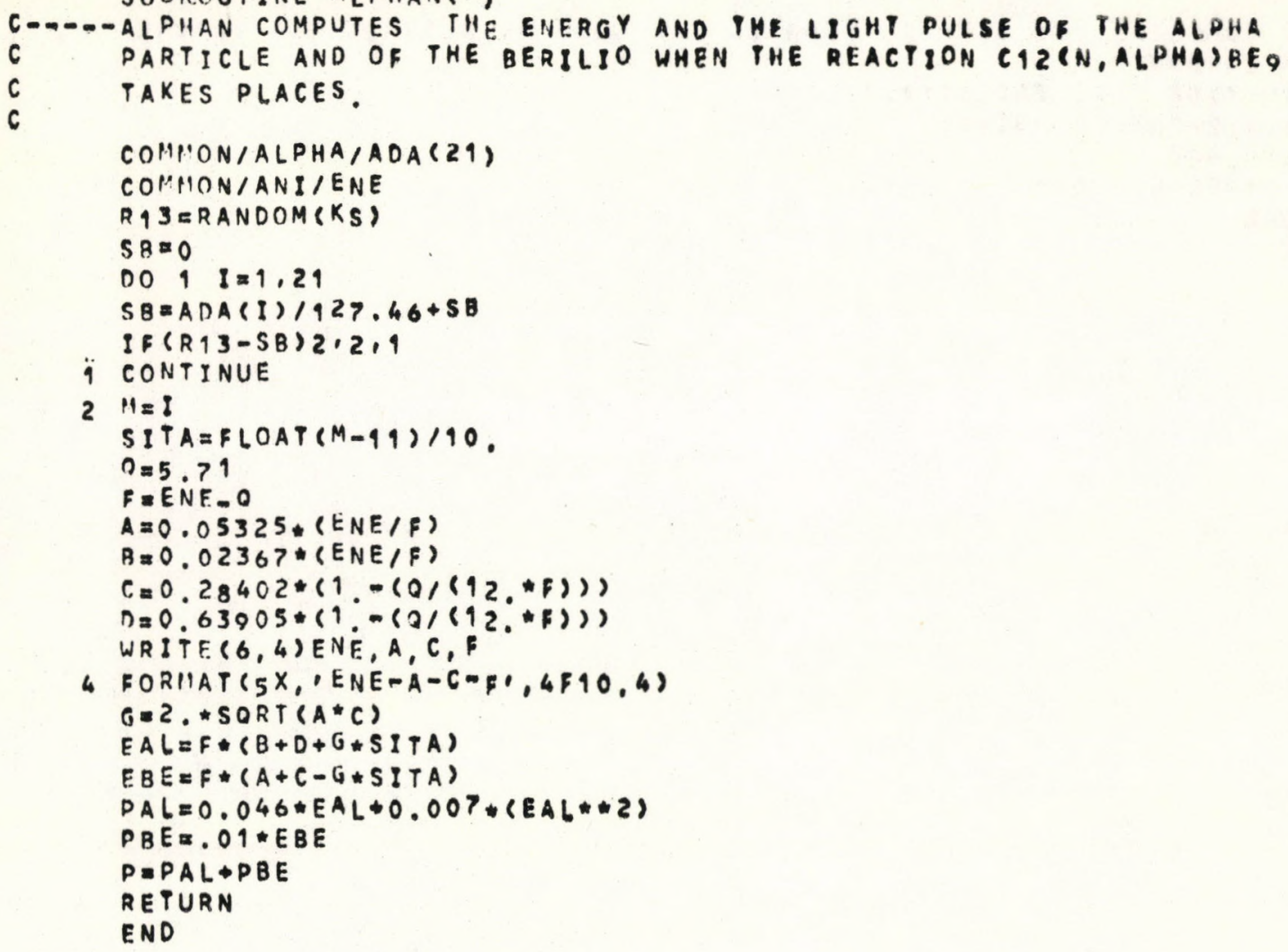


FUNCTION RANDOM (KS)

C $\rightarrow-$-RANOOMCCOMPUTES RANDOM NUMBERS UNIEORHLY DISTRIBUTED BETWENROOQ $I Y \equiv K S=655^{39}$ If $(I Y) 5,6,6$

$5 \quad I Y=\{Y+2947483647+1$

$6 Y F L=I Y$

RANDOMEYFL". $46566938=9$

$K S=I Y$

RETURN

END 
FUNCTION SEGN(X)

C-NO-SEGN IS ONLY PO PROVIDE A SIGN I+ OR - IE THE ARGUMENT IS NFGATIVE OR POSITIVE.

If $(X) 10,20,20$

10 SEGH $=1$.

RETURN

20 SEGN=-1.

RE TURN

EN D 
A GAHDA

RUNCTION ALAMOA (ENE)

$C=-A L A M D A$ COMPUTES THE MEAN FREE PATH OF THE NEUTRON COMP:ON/LIL/SEEH(S), SEM $(96,2), \operatorname{PABM}(96,2)$

COMMON/JM/HN,RHC,A,B,G

COMPION PROB (5), TAB $(200,5), S E(200,5), S E E(5)$

CALL PROBA(LNE)

IF (ENE-0.09) $24,23,23$

23 DO $22 l=1,3$

22 SEE (I) $=S E($ IF IX (ENE $10 . \$ 0.5001)$, I)

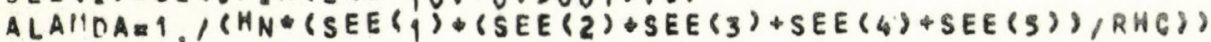
BO TO 25

$24 \quad 0021 \quad I=1,2$

24 SEEM(I) $=\operatorname{SEM}($ IFIX ( $(E ! I E * .01) \neq 900 . \$ .5001)$, I)

$A L A ! D A=1,1\left(H_{N} \oplus \operatorname{SEEM}(1)\right.$ S SEEM( 2$\left.\left.), R H C\right)\right)$

25 CONTINUE

RETURN

END 
- $35-$

OUT FOR SAMPLE PROBLEM 


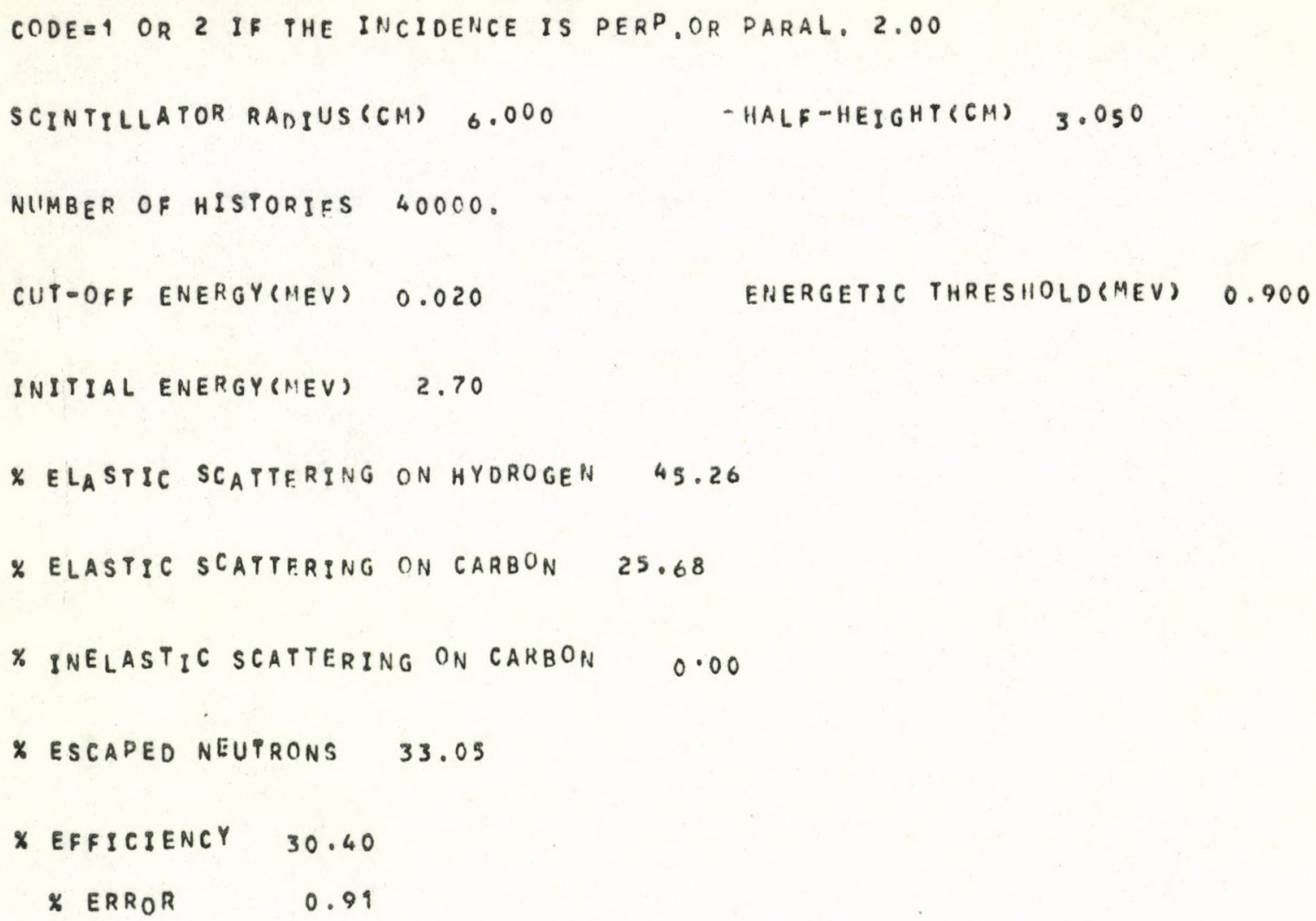





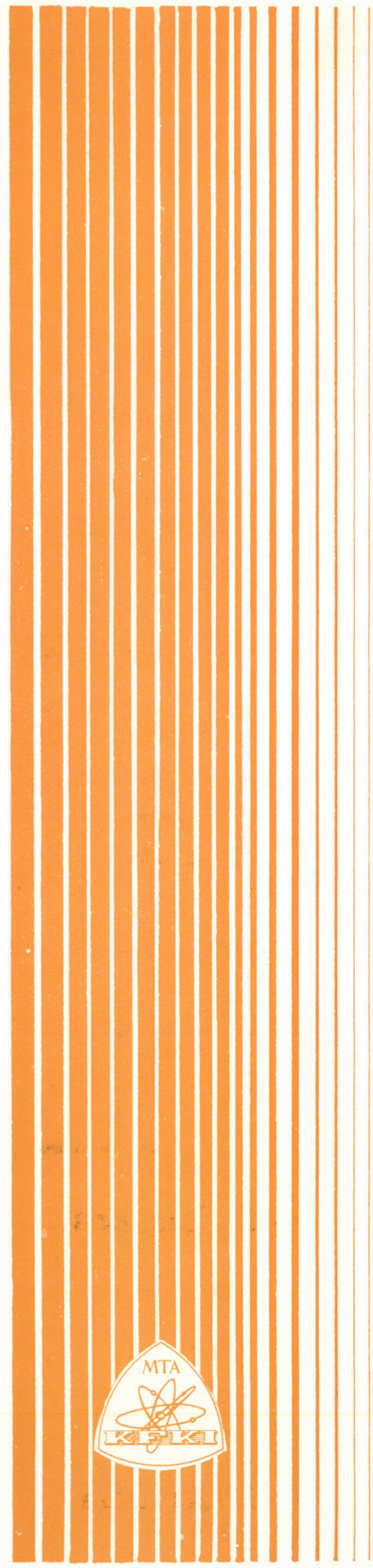

\author{
Kiadja a Központi Fizikai Kutató Intézet \\ Felelơs kıadó: Szegố Károly \\ Szakmai lektor: Kardon Béla \\ Nyelvi lektor: Harvey Shenker \\ példányszám: 310 Törzsszám: 79-762 \\ Készult a KFKI sokszorositó üzemében \\ Budapest, 1979. szeptember hó
}

